\title{
Anti-Romani terrorism in Europe
}

\author{
MIROSLAV MAREŠ
}

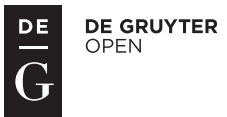

Politics in Central Europe (ISSN: 1801-3422)

Vol. 12, No. 2

DOI: 10.1515/pce-2016-0013

\begin{abstract}
This article analyzes terrorism against the Roma in Europe. It identifies acts of terrorism in violence that targets the largest stateless nation on the continent and categorizes this terrorism according to current research methods. Focusing on events in both Western and Eastern Europe, the article analyses and compares the most significant terrorist acts against the Roma of recent years. It concludes that anti-Romani terrorism is heterogeneous in terms of tactics, strategies, and ideological justification, yet can usually be subsumed into the broadly conceived category of far-right terrorism. The variety of attacks suggests that terrorist acts are an offshoot of the broad spectrum of anti-Romani activity, and are influenced by contemporary trends in inter-ethnic violence.
\end{abstract}

\section{Key words: Romani people, terrorism, Europe, far right, racist violence}

\section{Introduction}

For several decades now, a wave of substantial anti-Romani violence has been present in Europe, a continent on which the Roma are the largest stateless ethnic group or nation. This article analyzes violence against the Roma throu$\mathrm{gh}$ the prism of terrorism. The issue is examined from the point of view of the victims-members of the Romani population or its constituent ethnicities. Building upon this basis, the strategies of the terrorists themselves are analyzed and categorized according to the generally respected typologies of terrorism. In order to do this, a framework for analysis is first introduced; this is based on the typologies of terrorism in general and those of far-right terrorism in

1 This article was written as part of the grant project GAČR GA408/11/0709 "Contemporary challenges of democracy in East Central Europe," funded by the Czech Science Foundation. Translated by Štěpán Kaňa. 
particular, as most acts of anti-Romani terrorism to date have been classified as right-wing extremism (Backes 2012: 61). The issue of anti-Romani violence is then described and an overview provided of those anti-Romani acts which fulfill the characteristics of terrorism and its various categories. In conclusion, the significance of anti-Romani terrorism is evaluated in view of its strategic use of violence.

The fundamental research question of the article is the following: what forms does terrorist violence against the Roma take in Europe? The complementary question is: how important is anti-Romani violence in terrorist strategies? To answer both, descriptive and historical methods are used, as well as an analytical approach that applies typologies to actual cases. Anti-Romani violence is not limited to Europe, it also appears in North America and the Middle East (Yild1z 2015); the focus of this article is, however, on the situation in Europe.

\section{Anti-Romani terrorism from the viewpoint of the typologies of terrorism}

There is no agreed definition of terrorism, either among experts or within the international community more generally. An analysis of the factors that make defining terrorism so difficult is beyond the scope of the present article; a number of renowned scholars have been involved in this effort, and the reader is referred to their findings (Graborsky - Stohl 2010, Martin 2013, Schmid 2011). The main causes are the normative viewpoints assumed and the heterogeneity of the phenomena described as terrorism. The normative issue is that the concept of terrorism has negative connotations, and thus there is a tendency not to use the discrediting term terrorist to describe oneself or one's allies.

The heterogeneity is linked to the great variety of violent acts that are described as terrorism. Among other things, there is discussion as to whether terrorism involves only subversive activities against those in power, or whether the term can also be used to describe repressive measures taken by power holders against their populations (e.g. the Stalinist purges in the Soviet Union). What constitutes a terrorist target is also problematic. According to some authors, one should speak of terrorism only when innocent civilians are targeted; others also consider peacetime attacks against power holders and military/security personnel as terrorism. The issue of terrorism during war also presents a challenge for conceptualizing the phenomenon. There are more such problems (Mareš 2005: 27-31).

Well-known terrorism scholar Alex P. Schmid has analyzed several hundred definitions of terrorism and identified the following core features:

1. The demonstrative use of violence against human beings;

2. The (conditional) threat of (more) violence;

3. The deliberate production of terror or fear in a target group; 
4. The targeting of civilians, non-combatants and innocents;

5. The purpose of intimidation, coercion and/or propaganda;

6 . The fact that it is a method, tactic or strategy of waging conflict;

7. The importance of communicating the act(s) of violence to larger audiences;

8. The illegal, criminal, and immoral nature of the act(s) of violence;

9. The predominantly political character of the act;

10. Its use as a tool of psychological warfare to mobilize or immobilize sectors of the public (Schmid 2011: 74).

Many of the characteristics cited above are present in one of the most accepted definitions of terrorism, adopted in UN Security Council resolution 1566 (2004). This resolution describes terrorism as "criminal acts, including against civilians, committed with the intent to cause death or serious bodily injury, or taking of hostages, with the purpose to provoke a state of terror in the general public or in a group of persons or particular persons, intimidate a population or compel a government or an international organization to do or to abstain from doing any act, which constitute offences within the scope of and as defined in the international conventions and protocols relating to terrorism" (UN Security Council 2004).

Thus, the essence of terrorism is that it is aimed at targets not directly associated with combatants in a military conflict and, by doing so, intimidates a broader public (government, the general public, or a specific group of people). In terms of terrorism being employed as a strategy, what matters is that terrorists or terrorist groups choose to commit terrorism when they deem it suitable for achieving their goals. Terrorism is therefore an intentional excessive anthropogenic threat.

The definition of terrorism is difficult, and so is its typology. Acts of terrorism can be classified according to many criteria. One of them focuses on the ideological motivations or goals that drive the terrorists. In this respect, one can speak of religious, extreme-left, extreme-right, ethnic-territorial and single-issue terrorism. A discussion is underway as to whether violence employed in the support of democratic ideas-for example, against a dictatorship-should be classified as terrorism. Another possible criterion for defining terrorism focuses on whether it must be undertaken by purely non-state subjects, or whether state actors may be variously involved (by funding, secret services activities, etc.; Kraus 2014). Terrorism can be committed by groups or individuals with variously weak or strong links to an organization or movement, and includes acts committed by so-called lone wolves.

In terms of the strategies in support of which terrorist methods are deployed, one may consider the simple intimidation of an adversary by the brutality of a terrorist act (or threat thereof), or a more elaborate approach that aims 
to recruit new supporters by means of the terrorist act (the terrorists' self-understanding as an avant-garde). Acts of terrorism against persons or groups which are perceived by a significant segment of society as aberrant, can send out a strong message that the perpetrators would be better able to secure law and order than the existing powers (vigilante terrorism). Terrorism can also be used to create chaos, or organize false-flag operations (imputed to political opponents), so that the political wing of the terrorist organization gains the sympathies of the general public to the detriment of those to whom the attacks have been ascribed (a strategy of tension). All of these variants of terrorism send out an ideological message, whether by the act itself (the symbolism of targets, etc.) or in accompanying communications (Bötticher - Mares 2012: 237).

All of these categories need to be understood as an analytical framework; the typologies may complement each other, and individual categories within a typology may permeate; for example, ethnic terrorism may be motivated by a far-left, far-right or religious ideology, or vigilante terrorists may think of themselves as an avant-garde. Terrorism may also be classified according to the means of implementation (e.g. suicidal terrorism), its geopolitical origin (Middle East terrorism), the space in which it is executed (cyber terrorism) or the targets it chooses (airline terrorism). Within the last category, the targets can also be of a group character (for instance, anti-Semitic terrorism), an important point for defining anti-Romani terrorism.

Existing studies on terrorism that have at least partially concerned themselves with violence against the Roma have mostly analyzed extreme-right terrorism (Backes 2012: 61, Mareš 2014, Ravndal 2015: 26) and, to a small degree, lone-wolf terrorism (Hartleb 2013: 83), and terrorism within a regional framework (Mareš 2011: 243-244, Marton 2011: 18-19). Hence one needs to focus, above all, on an analytical framework for the study of extreme-right terrorism.

Scholars have chiefly studied this kind of terrorism either in Western Europe and the US (Holbrook - Taylor 2013, Ravndal 2015), or in Russia (Laryš - Mareš 2011). Although anti-Romani violence does appear in these areas, it is not as prominent there as in East-Central and South East Europe (Mudde 2005: 274275). Yet the study of anti-Romani terrorism must be conceived in a broader geopolitical context. Violence against the Roma materializes in many places where stateless nations are to be found.

In the mid-1990s, Ehid Sprinzak undertook a global summary analysis of extreme-right terrorism (without explicitly mentioning violence against the Roma). He categorized extreme-right terrorism as follows:

1. Revolutionary terrorism (seeking to establish a far-right regime);

2. Reactive terrorism (seeking to preserve a far-right regime or restore its power);

3. Vigilante terrorism (seeking to establish or maintain order in an existing regime); 
4. Racist terrorism (seeking to establish a society based on racial hierarchy);

5. Millenarian terrorism (terrorism of religious groups believing that the end of the world is imminent and they have been chosen; they use terrorist violence against the society of $\sin$ that surrounds them);

6 . Youth counterculture terrorism (terrorist violence is used as part of youth-counterculture rebellion; as Sprinzak points out, only a small part of the violence committed by subcultures or countercultures such as skinheads can be classified as terrorism) (Sprinzak 1995: 22-37).

An important criterion within the typology of terrorism is selectivity. Maxmilián Strmiska writes about the "individualization" of selectively targeted victims on the one hand, and he describes a general framework of the choice of victims of non-selective terrorism on the other hand (Strmiska 2001: 41). An affiliation to a specific ethnic, religious or political group can be a specific criterion of partial selectivity of the victim from the point of view of a terrorist perpetrator. Another approach can be connected with symmetry, or asymmetry, of a terrorist group in relation to the targeted group (Souleimanov, 2006: 20-21). The concept of symmetric or asymmetric threats can also be connected with so-called "group security" (Juříček, Rožňák, 2014: 92), which is related to the security of specific societal groups within the state, for example, ethnic entities. These entities can be threatened by violent representatives of the more powerful groups.

Bearing in mind the definitions and typologies of terrorism provided above, the key criterion for identifying anti-Romani terrorism is that of excessive violence targeted specifically against the Roma. It is terrorism aimed against an ethnic group or a stateless nation, i.e. people who do not formally hold power. The objective is to send a threatening message to the Roma people either locally or more widely. In order to qualify as terrorism as defined above, the act in question must be motivated by at least a simple strategic calculation; it cannot be, for instance, a random skirmish between two youth gangs. In many cases, instances of extreme-right terrorism overlap with those of hate crime (Transnational Terrorism, Security \& Rule of Law 2008: 5); the distinguishing features of terrorism are, precisely, the exceptional brutality of the violence involved, the presence of a strategic calculus, and the dissemination of a threatening message.

\section{Anti-Romani violence in contemporary Europe}

Even with this definition, it is difficult to differentiate anti-Romani terrorism from other forms of anti-Romani violence, as such violence can take very different forms, and an element of intimidation of the Romani community (or part thereof) is present in many of them. There are currently about 12 million Roma in the world (European Union 2015). Roma are considered an ethnic group, or the sum of various subethnic groups, by some scholars (Jakoubek 
2008), or as a stateless nation by other scholars and by a large part of Roma representation) (Pečínka 2009). A significant proportion of them are exposed to marginalization, which according to some definitions fulfils the conditions of what has been described as structural or systemic violence (e.g. segregation in education, failures in child protection, denial of access to health care, and social assistance, etc.; European Roma Rights Centre 2012c). A more detailed typology of violence against the Roma can be found in the following scheme, devised on the basis of an analysis undertaken by the European Association for the Defense of Human Rights (2012).

\section{Table 1: Violence against the Roma}

\begin{tabular}{|l|l|l|}
\hline State violence & $\begin{array}{l}\text { Physical violence against Roma } \\
\text { by individuals or groups }\end{array}$ & Social violence \\
\hline $\begin{array}{l}\text { - Anti-Roma rhetoric by political } \\
\text { parties }\end{array}$ & $\begin{array}{l}\text { - Racist bias maintained by the } \\
\text { media }\end{array}$ & $\begin{array}{l}\text { - Poor quality, unsanitary hous- } \\
\text { ing }\end{array}$ \\
\hline $\begin{array}{l}\text { - Violence of the authorities } \\
\text { towards Roma }\end{array}$ & $\begin{array}{l}\text { - Roma as victims of violence by } \\
\text { the people }\end{array}$ & $\begin{array}{l}\text { - Exclusion from the health } \\
\text { system }\end{array}$ \\
\hline - Detention of Roma people & $\begin{array}{l}\text { - Roma people particularly are } \\
\text { victims of trafficking }\end{array}$ & $\begin{array}{l}\text { - Segregation in the educational } \\
\text { system }\end{array}$ \\
\hline - Segregation of Roma & & - Difficult access to employment \\
\hline $\begin{array}{l}\text { - Illegal sterilization of Roma } \\
\text { women }\end{array}$ & & \\
\hline $\begin{array}{l}\text { - Official refusal to recognize the } \\
\text { Nazis' Romani genocide }\end{array}$ & & \\
\hline
\end{tabular}

Source: European Association for the Defense of Human Rights (2012)

Even if we focus solely on physical violence against the Roma by individuals or groups, the spectrum of its forms is very broad. Anti-Romani violence has been developing ever since the arrival of the first Roma into Europe, where they have been subjected to repression. Examining the strategies of those opposed to the Roma today, one finds references to historical forms of anti-Romani violence, such as the brutal punishments of European rulers meted out to the Roma since their arrival in Europe, or the celebration of the Romani genocide committed during the Nazi period. For instance, at a demonstration in Varnsdorf, Czech Republic, in 2011, the inscription on one woman's T-shirt read "Revive HitlerRoma to the gas chamber" (Policie České republiky 2011).

The main forms of non-state, physical anti-Romani violence in contemporary Europe are the following: 
1. Anti-Romani riots, in which a crowd of people, usually led by extreme-right activists, attempts to attack housing estates inhabited by Romani people (e.g. in Bulgaria or the Czech Republic);

2. Non-state vigilante patrols, usually made up of members of extreme-right paramilitary organizations, who intend to prevent Romani crime;

3. Non-premeditated, situational violence against the Roma;

4. Premeditated extremist violence, which does not reach the intensity of terrorism;

5. Terrorist violence against the Roma;

6 . The planning of a Romani genocide or ethnic war against the Roma (Mareš 2012: 285-294).

State violence might be committed by police forces when they take unreasonable measures against the Roma (for example, anti-racism organizations have criticized the steps taken during the clearing out of Romani camps by French authorities; Amnesty International 2015: 15-17), or, in specific cases, by quasi-state military forces (e.g. the violence committed on the Roma during the crisis in Ukraine by the armed forces of the separatist republics; Organization for Security and Cooperation in Europe 2014: 28-29).

The total extent of anti-Romani violence is difficult to estimate, as no clear and comprehensive statistics of these acts are kept. Internationally, the Organization for Security and Cooperation in Europe does some work on the issue as part of its monitoring of hate crimes; however, only a handful of states and international organizations supply information as part of this monitoring, and statistics are available only from 2008 onwards (Organization for Cooperation and Security in Europe 2015). Materials by other non-governmental organizations contain merely listings from certain countries or areas (Amnesty International 2015, European Roma Rights Centre 2012a, b). Studies do exist that investigated the situation in the 1990s; however, they are focused on other aspects of anti-Romani racism and exclude statistics concerning its victims (Mudde 2005). One can also find thorough case studies focused on individual countries (Kučera 2011).

An approximate but expert estimate on the basis of the above-mentioned sources indicates that since 1989 about 500 Roma have been killed in Europe in racially-motivated acts of physical interpersonal violence, about two-thirds of them during the 1990s. The number of injured has been greater by an order of magnitude, and apparently a large part of the Romani community fears such attacks. Though most often occurring in East-Central and South East Europe, in recent years anti-Romani violence has also flared up in Eastern Europe (Ukraine) and Western Europe (in connection with the migration of Roma from Central and Eastern Europe) (Human Rights First 2008: 111-112). 


\section{Specifying anti-Romani terrorism}

Anti-Romani violence in Europe covers a broad spectrum, creating among the Romani population a widespread atmosphere of fear, which acts such as planned attacks, mass anti-Romani protests featuring elements of violence, attempts at lynching real or supposed Romani criminal offenders, etc contribute to. For that matter, even in the study of other forms of terrorism, mob attacks directed by terrorists that have atrocious consequences are sometimes described as terrorism, for example, the killing of the U.S. ambassador in Libya in 2012 when a mob stormed the embassy (United States Department of State 2013: 6).

Considering such acts of anti-Romani countercultural or subcultural violence, one observes elements of at least some premeditation and attempts to intimidate the Romani community in a number of deeds not otherwise described as terrorism, thus rendering them terrorist in character. For instance, when racist skinheads mounted an assault in Písek in the Czech Republic in 1993, they had planned a punitive expedition against the Roma in a specific town. During this expedition, a young local Rom was murdered, having been driven into the river where he drowned. This was real intimidation of the Romani community in the Czech Republic (Mareš 2014).

Subcultural violence-committed in particular by skinheads-has been behind the deaths and injuries of many Roma in Central and Eastern Europe, especially during the 1990s and 2000s. As already indicated above, within this violence one must differentiate various forms of attack on the Roma. Racist skinheads, who were dominant among the young extremist groups, were responsible for the overwhelming majority of these attacks. Yet there were also anti-racist and leftist currents within the skinhead movement, for example, Skinheads Against Racial Prejudice (SHARP). Nonetheless, from around 2005 onwards these groups were gradually replaced by new subcultural phenomena, principally the Autonomous Nationalists (Vejvodová 2014: 80-88).

Within the skinhead subculture groups appeared that began to think of themselves as the main vehicles of violent and armed struggle. Principally these were branches of the organizations Hammerskins Nation (HSN, founded in the USA in the late 1980s) and Blood \& Honour (established at the same time in the UK). Originally created as an independent entity in Great Britain, Combat 18 gradually associated itself with Blood \& Honour, serving as its militant wing (Bötticher - Mareš 2013).

As early as the first half of the 1990s, these organizations expanded into Central and Eastern Europe, where the Romani population (alongside immigrants, leftist adversaries, etc.) became the targets of their hateful propaganda. Whether the specific attacks on the Roma that took place were committed by actual members of these groups or by people who were passive recipients of their propaganda without themselves being incorporated into the organizational structures of 
these groups is, however, difficult to judge. The judiciary did not always investigate these aspects in cases such as the murder of a Romani woman in Slovakia in 2000 or the attack in Vítkov, Czech Republic, in 2009 during which a two-year old girl suffered severe burns (Mayer - Odehnal 2010: 159-160). In other cases exhibiting the traits of terrorism, an organized background was not proved.

Even where such affiliations are proven, the cases are not necessarily judicially recognized as terrorism according to the prevailing law, for instance, due to the allegedly low intensity of violence and its consequences. An example of this is the arson attack committed in Aš, Czech Republic, on 26 February 2011 by two young neo-Nazis who claimed allegiance to the regional branch of Combat 18 Sudetenland (Vegrichtová 2013: 156). There have also been cases where an organization understood to be terrorist made threats against the Romani, but without violence occurring. For instance, Combat 18 in Northern Ireland made threats against Roma who had immigrated into the area from East-Central Europe (Breen-Smyth 2009).

More well-known is the case of Anders Breivik, who in 2011 aimed his act of terrorism against the government of Norway (though in actual fact he killed several civilians close to Norwegian government buildings) and young left-wing activists, whom he considered bearers of "cultural Marxism." In his manifesto Breivik also made mention of the so-called Romani question, proposing resettlement of the Roma into Eastern Anatolia (Berwick 2011: 1307).

All of the examples provided above fall into the definition of terrorism as broadly understood, though the exact designation may be a matter for discussion. In the following three case studies, a clear terrorist element has been identified in the form of intimidation by brutal violence, and this violence has claimed human lives. Nevertheless it needs emphasizing that, of the three examples, only the case of Franz Fuchs has been officially described as terrorism, in the documents of the Austrian government (Republik Österreich. Bundesministerium des Inneres 1999). At the time these acts were committed, there was no law in force in Austria that directly described certain behavior as terrorist. By contrast, the case from Hungary was not heard by the court as one involving terrorism. The same is true for the case from Bulgaria, where, furthermore, the real culprits remain to be convicted.

\section{Case-study: Bomb attack on Roma in Austria in 1995}

A bomb attack on Roma was committed on the night of 4/5 February 1995, near the village of Oberwart in Burgenland, Austria. A tripwire explosive device was attached to a sign stating "Roma back to India" (Roma zurück nach Indien), designed to look like a traffic sign and placed at a junction close to the municipality. The item was discovered, apparently shortly after midnight, by four Roma, who probably attempted to remove it. They were alleged to be members of a Roma 
patrol, which at that time regularly monitored the situation around Oberwart, as the local Romani population had faced threats there before (Ivan 2005). The bomb, containing $400 \mathrm{~g}$ of TNT, exploded, instantly killing all four Roma: Josef Simon (aged 40), Peter Sarközi (27), Karl Horvath (22) and Erwin Horvath (18). They were found by the uncle of two of the victims, who called the police (Tozzer - Zellsacher 1995: 163). The police initially suspected that a relative of the murdered men had constructed the explosive device. However, the next day a charge exploded in the town of Stinatz, largely inhabited by members of the Croatian minority. Thanks to a letter connected to the second attack, both bombings were ascribed to the Bajuwarische Befreiungsarmee (BBA) (Antifaschistisches Autorenkollektiv 1996: 31).

This putative organization was responsible for sending letter bombs and placing explosives in Austria and Germany from 1993 to 1996. A total of 25 letter bombs were sent in five lots, with an additional device dispatched in December 1996. The attacks were committed in Klagenfurt (where the explosive was uncovered by police officers in time), Oberwart and Stinsatz. The main victims of the attacks were members of ethnic minorities, persons of foreign origin, and public figures known for helping immigrants and minorities. Nine letters claiming responsibility for the attacks were received (Republik Österreich. Bundesministerium des Inneres 1999: 50). As the overview of the attacks below shows, Roma were only attacked directly in Oberwart; they were, however, the only group to have suffered fatalities as a consequence of the incidents.

\section{Table 2: Attacks by the Bajuwarische Befreiungsarmee}

\begin{tabular}{|c|c|c|c|}
\hline Series/Attack & Date & Targets & Results of the attacks \\
\hline $\begin{array}{l}\text { First series of } \\
\text { letter bombs }\end{array}$ & December 1993 & $\begin{array}{l}\text { - August Janisch, pastor from Sty- } \\
\text { ria involved in aid to refugees } \\
\text { - Helmut Zilk, then mayor of } \\
\text { Vienna } \\
\text { - Helmut Schüller, head of the } \\
\text { Church organization Caritas, } \\
\text { which aids immigrants } \\
\text { - Silvana Meixner, ORF TV station } \\
\text { journalist for minorities } \\
\text { - Wolfgang Gombocz, activist of } \\
\text { the Slovenian cultural union in } \\
\text { Steiermark } \\
\text { - Madeleine Petrovic and Terezia } \\
\text { Stoisits, two Green Party politi- } \\
\text { cians helping immigrants } \\
\text { - Johanna Dohnal, then minister } \\
\text { for women } \\
\text { - ARGE (an association facilitat- } \\
\text { ing the employment of foreign } \\
\text { nationals) } \\
\text { - Islamic Immigration Aid Society }\end{array}$ & $\begin{array}{l}\text { Four wounded (Janich, Zilk, } \\
\text { Meixner and the clerk at a law } \\
\text { office in Vienna who opened the } \\
\text { letter addressed to the Islamic } \\
\text { Immigration Aid Society), six of } \\
\text { the ten bombs were seized and } \\
\text { defused. }\end{array}$ \\
\hline
\end{tabular}




\begin{tabular}{|c|c|c|c|}
\hline $\begin{array}{l}\text { Pipe bomb in } \\
\text { Klagenfurt }\end{array}$ & 24 August 1994 & $\begin{array}{l}\text { - Driving school in Klagenfurt } \\
\text { (Slovenian, according to the } \\
\text { perpetrator) }\end{array}$ & $\begin{array}{l}\text { Bomb found, exploded in the } \\
\text { detector during the police inves- } \\
\text { tigation. Three police officers } \\
\text { were wounded; Theo Kelz lost } \\
\text { both hands. }\end{array}$ \\
\hline $\begin{array}{l}\text { Second series of } \\
\text { letter bombs }\end{array}$ & October 1994 & $\begin{array}{l}\text { - A publishing house in Kla- } \\
\text { genfurt that issued works by } \\
\text { Slovenian writers } \\
\text { - Advisory centre for foreigners } \\
\text { at the Dornbirn diocese } \\
\text { - AG Papier Hallein factory (em- } \\
\text { ployed foreigners) } \\
\text { - The company Stift Wilten (help- } \\
\text { ful to foreigners) }\end{array}$ & $\begin{array}{l}\text { All four bombs uncovered, no } \\
\text { injuries. }\end{array}$ \\
\hline $\begin{array}{l}\text { Pipe bomb in } \\
\text { Oberwart }\end{array}$ & 4 February 1995 & $\begin{array}{l}\text { - Inhabitants of a Romani settle- } \\
\text { ment, bomb placed at nearby } \\
\text { junction }\end{array}$ & $\begin{array}{l}\text { Four Roma killed: Josef Simon, } \\
\text { Peter Sarközi, Karl Horvath and } \\
\text { Erwin Horvath. }\end{array}$ \\
\hline $\begin{array}{l}\text { Explosive charge } \\
\text { in Stinatz }\end{array}$ & 6 February 1995 & $\begin{array}{l}\text { - Croatians from the village, } \\
\text { bomb disguised as a spray can }\end{array}$ & $\begin{array}{l}\text { Bomb exploded when waste } \\
\text { container was being handled, } \\
\text { seriously injuring employee of } \\
\text { waste-disposal services Erich } \\
\text { Preißler. }\end{array}$ \\
\hline $\begin{array}{l}\text { Third series of } \\
\text { letter bombs }\end{array}$ & June 1995 & $\begin{array}{l}\text { - Arabella Kiesbauer, dark- } \\
\text { skinned presenter of the TV } \\
\text { station Pro } 7 \text { in Munich } \\
\text { - Intercontact, a mediatory } \\
\text { agency in Linz } \\
\text { - Dietrich Szameit, deputy mayor } \\
\text { in Lübeck } \\
\end{array}$ & $\begin{array}{l}\text { Three people wounded } \\
\text { (Kiesbauer and Szanmeit were } \\
\text { unharmed, as the letter bombs } \\
\text { were opened by their colleagues, } \\
\text { Sabine Dammann in Munich and } \\
\text { Thomas Rhoter in Lübeck). }\end{array}$ \\
\hline $\begin{array}{l}\text { Fourth series of } \\
\text { letter bombs }\end{array}$ & October 1995 & $\begin{array}{l}\text { - Maria Loley, refugee aid worker } \\
\text { - Mahmoud Abou-Roumie, Syrian } \\
\text { doctor } \\
\text { - A medical couple from Korea }\end{array}$ & $\begin{array}{l}\text { Two wounded (the aid worker } \\
\text { and the doctor; the bomb ad- } \\
\text { dressed to the Korean couple } \\
\text { was intercepted). }\end{array}$ \\
\hline $\begin{array}{l}\text { Fifth series of } \\
\text { letter bombs }\end{array}$ & December 1995 & $\begin{array}{l}\text { - Office of the United Nations } \\
\text { High Commissioner for Refu- } \\
\text { gees (UNHCR) in Vienna } \\
\text { - An Indian family living in Vienna } \\
\text { - A dating agency based in } \\
\text { Hungary } \\
\text { - Angela Resetarits, mother of } \\
\text { three sons of Croatian descent, } \\
\text { who were well-known in cul- } \\
\text { tural and media circles in favor } \\
\text { of immigration }\end{array}$ & $\begin{array}{l}\text { Two bombs exploded in the mail- } \\
\text { box, wounding one passer-by; } \\
\text { two others were intercepted. }\end{array}$ \\
\hline $\begin{array}{l}\text { The last letter } \\
\text { bomb }\end{array}$ & December 1996 & $\begin{array}{l}\text { - Lotte Ingrisch, writer, stepmoth- } \\
\text { er of the then-minister of the } \\
\text { interior, Caspar Einem }\end{array}$ & Bomb intercepted and defused. \\
\hline
\end{tabular}

Sources: APA 2013, Republik Österreich. Bundesministerium des Inneres 1999, Tozzer - Zellsacher 1995.

Responsibility for the attacks was claimed by the putative group whose full name was Salzburger Eidgenossenschaft - Bajuwarische Befreiungsarmee (The Salzburg Confederation - Bajuvarian Liberation Army, BBA). Based on German nationalist ideas, the, BBA promoted in its letters an ethnically pure German Austria without foreigners and ethnic minorities. The name alluded to the 
Germanic tribe of the Bajuvari, who, around the middle of the first millennium $\mathrm{AD}$, settled in parts of what is today Bavaria and Austria. However, the letter writer also signed off using fictitious names referring to important figures from Austrian history, such as Odilo, the eighth-century fighter against the Slavs in Carinthia; Siegfried Mahrenberg, the thirteenth-century leader of the Styrian uprising against Přemysl Otakar II; Friedrich II der Streitbare, the thirteenth-century ruler; Graf Ernst Rüdiger von Starhemberg, one of the victors over the Turks who laid siege to Vienna in 1683; and Andreas Hofer, the leader of a Tyrolean uprising at the time of the Napoleonic wars. One of the letters also questioned the holocaust of the Jews, calling it a fabrication (Tozzer - Zellsacher 1995: 139-214).

In the end only one perpetrator was apprehended. This occurred on 1 October 1997 during a police check on a driver whom two women had accused of stalking them. Upon the arrival of the police, the driver detonated an improvised explosive device, losing both of his hands. The perpetrator was Franz Fuchs from Obergralla, Austria, born in 1949. At the time of his arrest, Fuchs was unemployed, his most recent job having been as a measurement technician. He suffered from emotional and psychological issues about his low social standing and his qualities being insufficiently appreciated. He had been unable to complete his university education due to a lack of funding. He did not have a permanent partner (he allegedly experienced issues during a relationship he had with a Slovenian woman) and suffered from sexual anxiety. He thought the termination of his last employment was unjust (Müller 2006: 34). He put the blame for his problems on foreigners and members of ethnic minorities.

On 10 March 1999, Franz Fuchs was given a life sentence for the crimes of murder, attempted murder, grievous bodily harm, intentional endangering by explosives, aggravated blackmail, serious damage to property, and coercion of the federal parliament, the federal government, the Constitutional Court, the Supreme Administrative Court, or the Supreme Court, as well as the offence of coercion of Bundesland (Müller 2006: 33). On 26 December 2000, Fuchs committed suicide in prison.

The official version was that Fuchs was the, BBA's only member, but this has been called into question by various authors (Scheid 2001). Various conjectures exist as to Fuchs's accomplices, and the possibility that he was merely a cover. With respect to anti-Romani terrorism, the version proposed by Ana Maria Ivan is interesting: she attributes the, BBA attacks as well as the bombing in Oberwart to operatives of the former Romanian secret service, Securitate. One of Ivan's arguments is that in early June 1995 seven letter and parcel bombs were sent from Austria (Graz, Salzburg, Klagenfurt, and Innsbruck) to politicians in Romania who were members of the Hungarian, German, and Romani minorities, including the Romani political activist Gheorge Nicolae. Ivan spoke with a relative of two of those murdered in Oberwart, who said that one woman 
had made threats to his family over the telephone. One of these two above mentioned persons allegedly met Fuchs accidently in 1994, and spoke to him in friendly terms and hence, supposedly, Fuchs had no reason to attack the Roma. By contrast, there were apparently some individuals who were looking to resolve disputes and had links with Romania (Ivan 2005). It needs to be emphasized that this is unconfirmed speculation by one author; the sender of the letter and parcel bombs from Austria to Romania was never apprehended, and the cases of the, BBA (Fuchs) and this series of bombs were not linked, according to the official investigation. Still, it is interesting that an anti-Romani element appears in both, within the context of their broader targets of multiple ethnic minorities.

Heeding now the official explanation, the case fell into a period of Austria's politics in which there was a substantial increase in anti-immigrant sentiment, which was accompanied by the rise of the party-political extreme right. At that time in Austria there was also a strongly militant extreme-right movement whose members were originally suspected of having committed the, BBA attacks. The Romani question was not dominant in either the, BBA campaign nor in Austrian politics of the time; yet memories of the attack remain evident within Austria's Romani community to this day. A memorial was erected at the place of the Oberwart attack, and on its twentieth anniversary a number of commemoration services for the victims were held at the site, some with the participation of Austria's President Heinz Fischer (Bundespräsident der Republik Österreich 2015).

\section{Case study: Death Squad in Hungary, 2008-2009}

The series of attacks that claimed the most lives among the Roma was committed by a group of racists in Hungary between 2008 and 2009. Though they issued no proclamations, or even the name of their group (if they used a name, this remains unknown), the media dubbed them the "Death Squad" (Halálbrigád), or described the case as the "murders of the Roma" (Romagyilkosságok). The group consisted of four individuals, Arpád Kiss, István Kiss, Zsolt Pető, and István Csontos, who over the period of their group's activities murdered six Roma and exposed 55 people to clear physical danger. They fired 78 gunshots and threw 11 Molotov cocktails at homes inhabited by Roma (Athena Institute 2013).

The members of the group were activists of the extreme right for many years, chiefly among the local skinhead movement in Debrecen. István Kiss took part in a 1995 attack on a synagogue there, later becoming a member of the local organization Bloody Sword (Véres Kard) and, subsequently, the Hungarian section of the Hammerskins. Arpád Kiss participated in events organized by Blood \& Honour in Budapest. István Csontos was a former soldier; he was involved in the Kosovo mission, where he also acted as an agent of military intelligence, his task being to report potential unrest among soldiers (Vágvölgyi 
2014: 4). Otherwise the perpetrators had ordinary jobs (sound engineer, cook and pastry cook). The attacks were planned from Debrecen and the targets chosen throughout Hungary (K. B. I. 2013). According to the information available, the plan of the four was to incite retaliation from the Roma against ethnic Hungarians, thus provoking a civil war in the country in which the Roma would be exterminated (Mareš - Tvrdá 2014: 12).

The perpetrators planned their attacks, in several cases, reconnoitering sites in advance. They used maps and satellite imagery, choosing some targets at random and others according to media reports, including those where there was increased tension between the Roma and the majority. They would drive to their destination, leaving their car parked at some distance and continuing on foot; then they would attack and withdraw. The attacks were mostly carried out at night, and the perpetrators used night-vision equipment. They started with attacks on property-though even in these there was the possibility of injuring or killing people-later shifting to purposeful murderous assaults on people. The group was very interested in how its activities were presented in the media, and this also contributed to the escalation of the group's violence (Kuria 2016, Vágvölgyi 2014).

\section{Table 3: List of attacks committed by the Death Squad in Hungary}

\begin{tabular}{|l|l|l|l|}
\hline Place & Date & Description of attack & Consequences \\
\hline Besenyszög & 7 March 2008 & $\begin{array}{l}\text { Brothers Kiss and Pető robbed } \\
\text { the house of Csaba G., a profes- } \\
\text { sional hunter. }\end{array}$ & Seven hunting weapons stolen. \\
\hline Debrecen & 2 June 2008 & $\begin{array}{l}\text { Brothers Kiss and Petö fired } \\
\text { two shots at a refugee camp } \\
\text { from a distance of 260 meters. }\end{array}$ & $\begin{array}{l}\text { Bullet hole in a window, one } \\
\text { inhabitant slightly injured. }\end{array}$ \\
\hline Galgagyörk & 20 June 2008 & $\begin{array}{l}\text { Brothers Kiss and Pető fired } \\
\text { shots at houses in the Romani } \\
\text { part of the municipality. }\end{array}$ & $\begin{array}{l}\text { Damage to property, lives of } \\
\text { several Roma put at risk. }\end{array}$ \\
\hline Piricse & 7 August 2008 & $\begin{array}{l}\text { Brothers Kiss and Pető threw } \\
\text { Molotov cocktails and shot at } \\
\text { two Romani houses. }\end{array}$ & $\begin{array}{l}\text { One Romani woman injured, } \\
\text { damage to property, lives of } \\
\text { several Roma put at risk. }\end{array}$ \\
\hline $\begin{array}{l}\text { Nyíradony- } \\
\text { Tamásipuszta }\end{array}$ & $\begin{array}{l}\text { 4 September } \\
2008\end{array}$ & $\begin{array}{l}\text { Arpád Kiss fired shots at a } \\
\text { house inhabited by Roma. }\end{array}$ & $\begin{array}{l}\text { Damage to property, lives of } \\
\text { about ten Roma put at risk. }\end{array}$ \\
\hline Tarnabod & 28 September & $\begin{array}{l}\text { Brothers Kiss and Pető threw } \\
\text { a Molotov cocktail at a house } \\
\text { and fired shots at several } \\
\text { others. }\end{array}$ & $\begin{array}{l}\text { Damage to property, lives in } \\
\text { danger (contrary to the expec- } \\
\text { tations of the perpetrators, } \\
\text { the houses shot at were not } \\
\text { inhabited by Roma). }\end{array}$ \\
\hline Nagycsécs & $\begin{array}{l}2008 \\
2008\end{array}$ & $\begin{array}{l}\text { Brothers Kiss and Pető threw } \\
\text { two Molotov cocktails and shot } \\
\text { at two Romani houses. }\end{array}$ & $\begin{array}{l}\text { Two casualties (József Nagy and } \\
\text { F. Nagy), one seriously injured } \\
\text { (Tibor Nagy), lives of other } \\
\text { Roma in danger, damage to } \\
\text { property. }\end{array}$ \\
\hline
\end{tabular}




\begin{tabular}{|l|l|l|l|}
\hline Alsózsolca & $\begin{array}{l}\text { 15 December } \\
2008\end{array}$ & $\begin{array}{l}\text { Brothers Kiss shot at several } \\
\text { Roma near their home. }\end{array}$ & $\begin{array}{l}\text { One injured with lasting conse- } \\
\text { quences (Krisztián Rontó). }\end{array}$ \\
\hline $\begin{array}{l}\text { Tatárszent- } \\
\text { györgy }\end{array}$ & $\begin{array}{l}23 \text { February } \\
2009\end{array}$ & $\begin{array}{l}\text { Brothers Kiss and Pető threw } \\
\text { two Molotov cocktails and shot } \\
\text { at a house and also shot at peo- } \\
\text { ple leaving the property. }\end{array}$ & $\begin{array}{l}\text { Father Róbert Csorba and his } \\
\text { young son shot dead; mother } \\
\text { and daughter Bianka Csorba } \\
\text { seriously injured, two other } \\
\text { family members in danger and } \\
\text { hospitalized. }\end{array}$ \\
\hline Tiszalök & 22 April 2009 & $\begin{array}{l}\text { Brothers Kiss and Csontos } \\
\text { (for the first time) opened } \\
\text { fire through the window of a } \\
\text { Romani house. }\end{array}$ & Jenő Kóka shot dead. \\
\hline Kisléta & 2 August 2009 & $\begin{array}{l}\text { Brothers Kiss, Pető and Csontos } \\
\text { assaulted a Romani house, } \\
\text { shooting at two victims. }\end{array}$ & $\begin{array}{l}\text { Maria Balogh shot dead, her 13- } \\
\text { year old daughter Tímea Pótor } \\
\text { seriously injured. }\end{array}$ \\
\hline
\end{tabular}

Sources: Kuria 2016, Vágvölgyi 2014

After a lengthy investigation, and apparently with the aid of the FBI, the perpetrators were apprehended on 21 August 2009 at a discotheque in Debrecen; weapons and munitions were found in an adjacent building (Vágvölgyi 2014: 9). On 6 August 2013, Arpád Kiss, István Kiss and Zsolt Pető were handed life sentences, István Csontos a 13-year prison sentence. A court of appeals upheld the verdict on 8 May 2015 and on 13 January 2016 Hungary's Supreme Court affirmed the life sentences for brothers Kiss and Pető (Kúria 2016). However, the judgments were handed down for murders, not for acts of terrorism, for which there was no provision in Hungarian criminal law at the time. The victims were awarded compensation by the state (Vágvölgyi 2014: 11).

The case occurred at a time of heightened tension between the majority populace and the Romani minority, at the turn of the first and second decade of the twenty-first century. This period was also characterized by the rise of the party-political extreme right in Hungary and, in particular, by the public activities of extreme-right paramilitary groups such as the Hungarian Guard. Although outlawed in 2009, this group spawned successor organizations. At the same time, paramilitary units were active in other countries of Central Europe and in the Balkans (Stojarová 2014). Nevertheless, a connection between the murders of the Roma and the Hungarian Guard or other paramilitary organizations was not proven. Since Roma were the Death Squad's primary target, the murders and the wider context of events seriously intimidated the Roma population in Hungary and were watched with apprehension by Romani activists throughout Europe (Pape 2016). 


\section{Case study: Bomb attack against Euroroma party offices in Bulgaria in 2012}

A case that bears the external signs of terrorism, but where no perpetrator was clearly identified, occurred in the town of Sandaski, Bulgaria on 29 July 2012. A bomb was planted outside the office of the Euroroma party and exploded. As the European Roma Rights Centre reported, the bomb "fatally injur[ed] 59-year-old Malin Iliev."

"On the day in question, Mr Iliev found a suspicious package and went to move it when it blew up in his hands. He was hospitalised and died a couple of days later. Investigations led to the arrest of four men who belonged to local nationalist groups. According to media reports, they left letters at the party headquarters before the attack, expressing their hatred of Roma." (European Roma Rights Centre 2012a).

Founded in 1998, the Euroroma party focuses on defending Romani rights, though it also counts ethnic Turks and Bulgarians among its members (Albert 2012). Although it gradually became one of the most influential Romani parties in Bulgaria, it has not been able to poll a serious share of the vote in parliamentary elections. As in other countries, the placing of Romani candidates on the lists of ordinary parties has proved a much more viable strategy in Bulgaria (Pečínka 2009: 46-50). The Euroroma party did, however, score some successes at the local level, including the Sandanski municipality (Albert 2012).

Shortly after the attacks, four young Bulgarian nationalists, Stojan S., Aleksandr A., Vasil G. and Nikolaj J. were accused of attempted murder. They were held in custody until 2013 and later investigated at liberty. However, as far as available information indicates, the case has not yet been judicially resolved. All four accused denied guilt and a campaign was mounted in their support (Bulgarski Nacionalni Sojuz 2014). In March 2014 court proceedings started in Blagoevgrad, but-according to the information available-the court has not yet arrived at a judgment. During the trial it transpired that the charges were based on information provided by a police informer, which the counsel for the defense disputed (Apostolova 2014). In January 2015, the former boss of the fan club of the CSKA Moscow football club supported the accused in court (BLIC 2015).

Whereas the attack itself was widely reported in Bulgaria and the world, information about the results of the trial is scarce (despite efforts by the author to obtain information from Bulgarian police experts on extremism). Sources from within the Bulgarian extreme right indicate that the trial continued in 2015 (Alter Media 2015).

The case needs to be understood in the context of escalated anti-Romani attitudes in Bulgaria and prior anti-Romani violence in the country. Things came to a head in the summer of 2011, when a wave of anti-Romani demonstrations occurred, spurred by the controversial behavior of the members of one Romani 
clan. According to NGO reports, at least 22 people were attacked in Bulgaria in the space of a year, of which three died (European Roma Rights Center 2012a).

In this atmosphere, the attack on the office of a party known for its defense of Romani rights had a strong symbolic resonance. The attack attracted international attention and Romani political organizations protested forcefully (Albert 2012). The site of the attack, its execution and consequences indicate that its purpose was to send a threatening message. Even if actual perpetrators are not convicted, the connection of this attack with extreme-right circles is highly probable, given the previous threatening letters sent to Euroroma in Sanadanski.

\section{Evaluation}

As the analysis of three main identified cases of terrorism against the Roma indicates, their aim was to intimidate the Romani population by attacks on selected members of this ethnic group or nation. The campaign of the Death Squad in Hungary was the most intensive and incurred the greatest number of casualties; the greatest loss of lives in a single attack was, however, recorded in the Oberwart, Austria, atrocity.

If we take into account Schmidt's criteria (Schmid 2011: 74), we can apply the majority of them to the above-analyzed cases of anti-Romani terrorism. The demonstrative use of violence against human beings is typical of all three cases, and the conditional threat of more violence is also included in these acts. Symbolism of these activities and clear intentions against Romani people are connected with the criterion of deliberate production of terror or fear in the target group. Targets of the terrorism were civilians and innocents. The purpose was intimidation and propaganda, despite the fact that Death Squad and Hungarian perpetrators did not publish their statements. However, these acts were by perpetrators perceived as part of a racial or ethnic conflict, and they were used for communication with a broader audience (including media attention). All cases researched were illegal/criminal acts. They were primarily politically motivated, because right-wing extremist ethnic or racial hate are serious political issues. The elements of psychological warfare to mobilize sectors of the public against Romani people are very likely also in the cases of the, BBA and the Death Squad; in the attack in Bulgaria it is not clear (more evidence is needed for this argument).

In terms of selectivity, Fuchs chose a site close to a Romani settlement where Roma were expected to be present; the Death Squad attacked several Romani homes and persons who were in their vicinity; and in Bulgaria the office of a political party connected with the Romani minority was attacked. The selection of targets according to the ethnic origin is typical of all three cases; however, in Bulgaria we can see a higher selectivity focused on a political party (this is 
a specific actor of Roma representation consisting of politically active members of the Roma community).

Whereas the attack in Bulgaria appears to be a one-off, in Austria and Hungary they were parts of campaigns. Although in Austria a Romani target was chosen only once, the, BBA campaign was also aimed against people aiding minorities, and, BBA letters contained anti-Romani diatribes (Tozzer - Zellsacher 1995). In Hungary, Roma were the main target, with the exception of the attack on the refugee camp. An ideological background can be identified particularly clearly in the case of the, BBA, which espoused pronounced German-Austrian nationalism and racism. In Hungary and Bulgaria, the perpetrators of the attacks issued no proclamations, but in Bulgaria the Euroroma party had been threatened previously. In Hungary, the function of the acts appears to have been propaganda, where the message is contained in the choice of targets and the execution of the attacks.

In Hungary one may speculate about neo-Nazi connections of the perpetrators on the basis of their pasts. As far as the suspects in the case in Bulgaria are concerned, they were strong nationalists with possible neo-Nazi links. Ideologically, all three attacks can be classified as right-wing extremism, though it needs to be emphasized that in Bulgaria the accused have not been convicted, and it is uncertain whether they were the perpetrators.

If these cases of anti-Romani violence are evaluated in terms of Sprinzak's criteria, the, BBA and Death Squad campaigns can be placed on the borderline between revolutionary and racist terrorism. If the version proposed by investigators is confirmed in Bulgaria, that case can be defined largely as countercultural terrorism. Given how the Romani minority is perceived, the presence of vigilantism can be considered in all three campaigns.

In sum, we can subsume the campaign of the, BBA as a form of lone-wolf terrorism (if we accept the official version) with a specific ultra-nationalist, right-wing extremist background, aimed against a broader set of targets (including the Romani people). Death Squad in Hungary was a systematic campaign of a well-organized and equipped small cell (probably with a neo-Nazi background, with elements of Hungarian national socialist legacy). The Romani people were the main targets of the campaign in Hungary (despite the fact that it started with an action against a refugee camp). In Bulgaria the bomb attack was a single action (it could be the start of a campaign; however, there is no clear evidence of this), probably connected with a small group, which arose from the subcultural right-wing extremist milieu. As this article shows, the anti-Roma terrorism can be identified in very different forms. 


\section{References}

Albert, Gwendolyn (2012): Bulgaria: Man dies as result of bombing of Euroroma office, Romea 1 August 2012, http://www.romea.cz/en/news/world/bulgaria-man-dies-as-result-of-bombing-of-euroroma-office (14 October 2014).

Alter Media (2015): Deloto za bombata v snadanski skalypen proces, http://www.altermedia. bg/news/view/261/deloto-za-bombata-v-sandanski-skalypen-proces, 23 March 2015 (20 December 2015).

Amnesty International (2014): "We ask for justice," Europe's failure to protect Roma from racist violence, http://www.amnesty.eu/content/assets/Reports/08042014_Europes_failure_to_protect_Roma_from_racist_violence.pdf (12 October 2014).

Antifaschistisches Autorenkollektiv (1996): Drahtzieher im braunen Netz. Ein aktueller Überblick über den Neonazi-Untergrund in Deutschland und Österreich, Konkret Literatur Verlag.

APA (2013): Franz Fuchs: Die Chronologie des Bomben-Terrors, Salzburger Nachrichten, 3 December 2013: http://www.salzburg.com/nachrichten/oesterreich/politik/sn/artikel/franz-fuchs-die-chronologie-des-bomben-terrors-85059/ (4 June 2014).

Apostolova, Vetina (2014): Kriminalniyat razuznavach B. Vasilev. Informator na policiyata posochi chetirimata arestuvani za bombata pred ofisa na Evroroma v Sandanski, Struma, 26 June 2014, http://struma.bg/news/26446/1/1/Kriminalniyat-razuznavach-B-Vasilev-Informator-na-policiyata-posochi-chetirimata-arestuvani-za-bombata-pred-ofisa-na-Evroroma-v-Sandanski. html (14 October 2014).

Athena Institute (2013): Identified domestic extremist groups, available at http://www.athenaintezet.hu/en/hate_groups/ (20 October 2014).

Backes, Uwe (2012): Formen und Transnationale Netze im Vergleich. Rechtsterroristische Kristallisationsfelder in Europa. Politische Studien 63 (443): 56-67.

Bundespräsident des Republik Österreich (2015): Erinnerung an das Oberwart-Attentat 1995 und die vier Opfer von Hass und Diskriminierung, http://www.bundespraesident.at/newsdetail/ artikel/-dc2ee14e6c/ (20 December 2015).

François-Xavier Bagnoud Center for Health and Human Rights at Harvard University (2014): Accelerating patterns of anti-Roma violence in Hungary, https://cdn2.sph.harvard.edu/ wp-content/uploads/sites/5/2014/02/FXB-Hungary-Report_Released-February-4-2014.pdf (accessed 20 December 2015).

Berwick, Andrew (2011). 2083 - A European Declaration of Independence, De Laude Novae Militae.

BLIC (2015): Duceto izrigina v syda na deloto za bombenija atentat v Sandanski, 28 January 2015, http://www.blitz.bg/news/article/316299.

Bötticher, Astrid - Mareš, Miroslav (2012): Extremismus. Theorien - Konzepte - Formen, Oldenbourg Verlag.

Bötticher, Astrid - Mareš, Miroslav (2013): Europaweite militante rechtsextremistische Netzwerke und Organisationen. Kriminalistik, 67 (10): 602-609.

Breen-Smyth, Marie (2009): Racism and violence in Northern Ireland: Romanian Roma driven out of Belfast, e-International Relations, July $7^{\text {st }}$ 2009, available at http://www.e-ir. 
info/2009/07/01/racism-and-violence-in-northern-ireland-romanian-roma-families-driven-out-of-belfast/ (11 October 2014).

Bulgarski Nacionalni Sojuz (2014): Vazhno. Kampania: Objektivnost za momtseeta ot Sandanski, 12 July 2012, available at http://bgns.net (12 October 2014).

European Association for the Defense of Human Rights (2012): Roma people in Europe in the 21st century: violence, exclusion, insecurity, available at: http://www.aedh.eu/plugins/fckeditor/userfiles/file/Discriminations\%20et\%20droits\%20des\%20minorit\%C3\%A9s/AEDH\%20 Roma\%20REPORT\%2017_4_2013(1).pdf (13 July 2014).

European Roma Rights Center (2012b): Attacks against Roma in Bulgaria: September 2011-September 2012, available at: http://www.errc.org/cms/upload/file/attacks-list-in-bulgaria.pdf (13 July 2014).

European Roma Rights Center (2012a): Attacks against Roma in Hungary: January 2008-September 2012, available at: http://www.errc.org/cms/upload/file/attacks-list-in-hungary.pdf (13 July 2014).

European Roma Rights Center (2012c): Factsheet: Roma Rights in Jeopardy, available at http:// www.errc.org/cms/upload/file/factsheet-roma-rights-record.pdf (13 July 2014).

European Union (2015): EU and Roma, available at: http://ec.europa.eu/justice/discrimination/ roma/index_en.htm (20 December 2015).

Graborsky, Peter - Stohl, Michael (2010): Crime and Terrorism, Sage.

Hartleb, Florian (2013): “Einsamer-Wolf-Terrorismus” - Neue Dimension oder drastischer Einzelfall? Was lernen wir aus dem Fall "Breivik" in Norwegen? SIAK-Journal 9 (4), 77-95: available at 21 June 2014, available at: http://www.bmi.gv.at/cms/BMI_SIAK/4/2/1/2013/ausgabe_4/ files/Hartleb_4_2013.pdf (12 January 2015).

Human Right Firsts (2008): 2008 Hate Crimes Survey, Human Rights Firsts.

Holbrook, Donald and Taylor, Max (2013): Introduction, in Holbrook, Donald - Currie, P. M and Taylor, M., eds., Extreme Right-Wing Political Violence and Terrorism, 1-13, Bloomsbury.

Ivan, Ana Maria (2005): Securitate Austria, available at http://www.ami25.at/securitate-austria/ index.php (20 December 2014).

Jakoubek, Marek (2008): Geneze Romů a Baršova ontologie per acclamationem aneb Debata pokračuje. In Jakoubek, Marek and Budilová, Lenka, eds.: Romové a Cikáni - Neznámí i známí. Interdisciplinární pohled, 257-288, Leda.

Juříček, Ludvík - Rožňák, Petr (2014): Bezpečnost, hrozby a rizika v 21. století. Key Publishing.

K. B. I. (2013): Háromszor Életfogytiglan. Zsaru, 14. August 2013, 4-5.

Kraus, Josef (2014): Íránský státní terorismus, Centrum pro studium demokracie a kultury.

Kučera, Michal (2011): Les violences contre les Roms en République tchéque. Revue des sciences sociales 46 (1): 102-113.

Kúria (2016): A Kúria pontot tett az egész országot felkavaró ügyre, 13 January 2016, available at http://lb.hu/hu/sajto/kuria-pontot-tett-az-egesz-orszagot-felkavaro-ugyre (17 January 2016). 
Laryš, Martin -Mareš, Miroslav (2015): Right-Wing Extremist Violence in the Russian Federation. Europe-Asia Studies 63 (1): 129-154.

Laqueur, Walter (2001): The New Terrorism. Fanaticism and the Arms of Mass Destruction, Phoenix Press.

Mareš, Miroslav (2005): Terorismus v ČR. Brno: Centrum strategických studií.

Mareš, Miroslav (2011): Terrorism-Free Zone in East Central Europe? Strategic Environment, Risk Tendencies, and Causes of Limited Terrorist Activities in the Visegrad Group Countries. Terrorism and Political Violence 23 (2): 233-253.

Mareš, Miroslav (2012):Vigilantism against the Roma in East Central Europe, in Backes, Uwe and Moreau, Patrick, eds.: The Extreme Right in Europe. Current Trends and Perspectives, 281-296, Vandenhoeck \& Ruprecht.

Mareš, Miroslav (2014): Leadership and Right-Wing Extremist Violence: Case Studies from the Czech Territory. In Milosevic Marko and Rekawek Kacper, eds: Perseverance of Terrorism: Focus on Leaders, 103-110, IOS Press.

Mareš, Miroslav - Tvrdá, Kateřina (2014): New forms of manifestation of extremist violence: Case study of East Central Europe. In Poczik, Szilveszter (ed.): Annual EENeT Conference 2012 in Budapest/HU. New Catalysts for Violent Extremism and Terrorism - Smoke on the Horizon?, 11-15, European Expert Network on Terrorism Issues.

Martin, Gus (2013): Understanding Terrorism. Challenges, Perspectives and Issues, 3rd Edition, Sage.

Martón, Peter (2011): Anti-terrorism in the Visegrad Framework: Less is More and Better. In Rękawek Kacper, eds.: Non-military aspects of security in V4 countries - prospects for co-operation, Polski Instytut Spraw Międzynarodowych, 11-25, available at https://www.pism. pl/files/?id_plik=8600 (13 April 2013).

Mayer, Gregor - Odehnal, Bernhard (2010): Aufmarsch. Die Rechte Gefahr aus Osteuropa. Residenz Verlag.

McAuley, James W (2013): Ulster Loyalist and Extreme Right-Wing Politics. In Taylor, Max - Currie, P. M. and Holbrook, Donald (eds.): Extreme Right-Wing Political Violence and Terrorism, 85-103, Bloomsbury.

Mudde, Cas (2005): Central and Eastern Europe Racist Extremism in Central and Eastern Europe, in Mudde, Cas: Racist Exremism in Central and Eastern Europe, 267-285, Routledge.

Müller, Thomas (2006): Einführung in die kriminalpsychologische Tatortanalyse. Fallbeispiel der Bajuwarischen Befreiungsarmee (BBA) (Teil 3), SIAK-Journal, 3 (3), 30-3, available at: http://www.bmi.gv.at/cms/BMI_SIAK/4/2/1/2006/ausgabe_3/files/Mueller_3_2006.pdf (12 January 2015).

Organization for Security and Cooperation in Europe (2014): Situation Assessment Report on Roma in Ukraine and the Impact of Current Crisis. (20 December 2015), https://www.osce.org/ odihr/124494?download=true. 
Organization for Security and Cooperation in Europe (2015): Bias against Roma and Sinti (20 December 2015), http://hatecrime.osce.org/what-hate-crime/bias-against-roma-and-sinti.

Pape, Markus (2016): Analýza: Verdikt mad'arského soudu je pravomocný. Za rasistické vraždy potvrdil doživotní tresty, Romea, 17 January 2016, available at http://www.romea.cz/cz/zpravodajstvi/verdikt-madarskeho-soudu-je-pravomocny-za-rasisticke-vrazdy-potvrdil-dozivotni-tresty (17 January 2016).

Pečínka, Pavel (2009): Romské strany a politici v Evropě, Doplněk.

Policie České republiky (2011): Shromáždění nebylo oznámené, http://www.policie.cz/clanek/ shromazdeni-nebylo-oznamene.aspx (12 June 2013).

Ravndal, Jacob Aasland (2015): Thugs or Terrorists? A Typology of Right-Wing Extremism and Violence in Western Europe. Journal for Deradicalisation 1 (3): 1: available at http://journals. sfu.ca/jd/index.php/jd/article/view/16 (20 December 2015).

Republik Österreich. Bundesministerium des Inneres (1999): Staatsschutzbericht 1998, available at http://www.bmi.gv.at/cms/bmi_verfassungsschutz/verfassungsschutzbericht_1998. pdf (14 January 2015).

Scheid, Hans-Christian (2001): Franz Fuchs—Doch kein Einzeltäter, Styria Premium.

Schmid, Alex P. (2011): The Definition of Terrorism, in Schmid, Alex P., eds: The Routledge Handbook of Terrorism Research, 39-98, Routledge.

Souleimanov, Emil (2006): Terorismus ve světle geneze ideologie a technologie soudobých konfliktů, in Souleimanov, Emil, eds.: Terorismus. Válka proti státu, 13-63, Eurolex.

Sprinzak, Ehud (1995): Right-Wing Terrorism in a Comparative Perspective: The Case of Split Delegitimization, in Bjørgo, Tjore, eds.: Terror From the Extreme Right, 17-43, Frank Cass.

Stojarová, Věra (2014): The Far Rigt in the Balkans, Manchester University Press.

Strmiska, Maxmilián (2001): Terorismus a demokracie. Pojetí a typologie subverzivního teroristického násilí v soudobých demokraciích, Masarykova univerzita.

Tozzer, Kurt and Zelsacher, Günter (1995): Bombenspuren. Briefbomben und politischer Terror. Holzhausen.

Transnational Terrorism, Security \& Rule of Law (2008): 20th Century Right Wing Groups in Europe. Prone to Extremism or Terrorism?, COT Institute for Safety, Security and Crisis Management: available at http://www.transnationalterrorism.eu/tekst/publications/Rightwing\%20 terrorism.pdf (7 June 2013).

UN Security Council (2004): UN Security Council Resolution 1566 (2004), available at http:// daccess-dds-ny.un.org/doc/UNDOC/GEN/N04/542/82/PDF/N0454282.pdf?OpenElement (6 June 2013).

United States Department of State (2013): Country Reports on Terrorism 2012, available at: http://www.state.gov/documents/organization/210204.pdf (6 June 2013).

Vágvölgyi, András B. (2014): Diskopartisanen. Eine Serie von Terroranschlägen und die Rolle von Justizwesen, Gesellschaft und Medien in Ungarn, Friedrich Ebert Stiftung, available at: http://library.fes.de/pdf-files/dialog/10958.pdf (20 December 2014). 
Vejvodová, Petra (2014): Transnational Forms of Contemporary Neo-Nazi Activity in Europe from the Perspective of Czech Neo-Nazis, Muni Press.

Yıldız, Yeşim Yaprak (2015): Nowhere to Turn: The Situation of Dom Refugees from Syria in Turkey, European Roma Rights Centre, available at http://kemalvuraltarlan.tripod.com/webonmediacontents/nowhere-to-turn-september-2015.pdf (20 December 2015).

Miroslav Mareš (1974) is professor at the Department of Political Science, Faculty of Social Studies Masaryk University. He is guarantee of the study program Security and Strategic Studies and researcher of the International Institute of Political Science. He focuses on the research of political violence and extremism, namely in the Central European context. He is a chair of the subgroup Right-wing, left-wing and separatist terrorism of the European Expert Network on Terrorism Issues (EENeT) and member of the editorial board of the Radicalisation Awareness Network (RAN) in the EU (2015-2016). He is a co-author (with Astrid Bötticher) of the book Extremismus (in German) and author or co-author more than 200 scientific articles, chapters and books.E-mail:mmares@fss.muni.cz 